\title{
ARID1B gene mutation in a patient with Coffin-Siris syndrome and Autism Spectrum Disorder
}

\author{
Nur Seda Gulcu ${ }^{1 \odot}$, Ali Karayagmurlu ${ }^{1 \odot}$ \\ 'Istanbul University, Istanbul Faculty of Medicine, Department of Child and Adolescent Psychiatry, Istanbul - Turkey
}

\begin{abstract}
Various factors may contribute to the emergence of Autism Spectrum Disorder (ASD). Genetic factors are particularly prominent in the etiology of ASD, and genetic syndromes may frequently accompany the disorder. Coffin-Siris syndrome is a genetic condition characterized by mental retardation, coarse facial appearance, hirsutism/hypertrichosis or skin with sparse hair, distal phalanx aplasia or hypoplasia, and fifth-finger and nail abnormalities. This genetic syndrome is accompanied by numerous different cardiac, genitourinary, gastrointestinal, ophthalmological, and craniofacial systemic abnormalities. ARID1B gene mutation is thought to be involved both in Coffin-Siris syndrome and in the etiology of autism. Although common genetic factors are involved in the etiologies of both diseases, our review of the literature revealed only one case report demonstrating an association between Coffin-Siris syndrome and ASD. This report describes a male patient aged 2 years and 10 months with ARID1B mutation showing Coffin-Siris syndrome and ASD comorbidity. It may be beneficial for clinicians to remember the coexistence of genetic syndromes in patients diagnosed with ASD and to request consultations from relevant departments for early diagnosis and treatment.
\end{abstract}

Keywords: Autism, ARID1B, Coffin-Siris syndrome, genetic

\section{INTRODUCTION}

Autism spectrum disorder (ASD) is a neurodevelopmental condition characterized by impaired social interaction, stereotyped repetitive behaviors, and a limited field of interest (1). Many significant factors play a role in the etiology of autism, including genetic factors (2). In recent years, numerous studies have investigated genetic factors, and many cases have been reported in the context of the relationship between different genetic syndromes and autism (3-5). Coffin-Siris syndrome is a genetic condition characterized by mental retardation, a coarse facial appearance, hirsutism/hypertrichosis or skin with sparse hair, distal phalanx aplasia or hypoplasia, and fifth-finger and nail abnormalities. Accompanying congenital abnormalities, cardiac, genitourinary, gastrointestinal and craniofacial abnormalities, ophthalmological problems, hearing abnormalities, and nutrition difficulties may also be present (6). The genetic transition of Coffin-Siris syndrome often occurs with de novo mutations. There is also an autosomal dominant transmission, at a lower level, caused by the heterozygous mutations of ARID1A, ARID1B, SMARCA4, SMARCB1, SMARCE1, and SOX11 genes (6). ARID1B gene mutation is one of the most common de novo mutations of Coffin-Siris syndrome (7). ARID1 is also one of the genes thought to be associated with

How to cite this article: Gulcu NS, Karayagmurlu A. ARID1B gene mutation in a patient with Coffin-Siris syndrome and Autism Spectrum Disorder. Dusunen Adam The Journal of Psychiatry and Neurological Sciences 2019;32:355-358.

Correspondence: Nur Seda Gulcu, Istanbul University, Istanbul Faculty of Medicine, Department of Child and Adolescent Psychiatry, Fatih, 34116, Istanbul - Turkey

Phone: +90 21241420 00/12832 E-mail: nursedagulcu@gmail.com

Received: April 04, 2019; Revised: April 29, 2019; Accepted: July 06, 2019 
the etiology of autism (7). However, we encountered only one case report concerning the coexistence of Coffin-Siris syndrome and ASD (8). This report describes a male patient aged 2 years and 10 months with ARID1B mutation and comorbid Coffin-Siris syndrome and autism.

\section{CASE}

A.K., aged 2 years and 10 months, was the subject of a consultation with the child and adolescent psychiatry outpatient clinic requested by the genetics department. History taken from the family revealed limited eye contact, failure to look when called, absence of focus of interest, unwillingness to point to any desired object, lack of interest in his peers, and 'flapping' motions when excited. Mental status examination revealed that he exhibited very little social interaction, lack of eye-to-eye contact, restricted facial expression, and repetitive movements such as 'flapping' when he was excited. The childhood autism assessment scale (CARS) was used for psychometric assessment. The case was assessed as severe autism with a CARS score of 38. ASD was diagnosed based on psychometric testing, DSM-based interview, and the history taken from the family. CoffinSiris syndrome was diagnosed by the genetics department, and heterozygous c.4176del(p.Tyr1392*) mutation in the ARID1B gene (6q25.3, NM_020732.3) was revealed by whole-exome sequencing. Following psychological assessment, the neurology, ophthalmology, and otorhinolaryngology departments were consulted to investigate potential comorbid diseases. The patient's threshold of hearing was within normal ranges, while ophthalmological examination revealed no visual impairment, and neurological examination showed no additional neurological disease. Psychoeducation concerning ASD was provided for the family. Special education support was recommended for the autism symptoms. Together with this special education, followup at three-monthly intervals was scheduled.

\section{DISCUSSION}

This report discusses a case of ASD and Coffin-Siris syndrome in a patient aged 2 years and 10 months. The number of case reports concerning the coexistence of genetic syndromes and autism is growing $(9,10,11)$. However, case reports concerning the coexistence of ASD and Coffin-Siris syndrome are very limited. Hersh et al. (8) reported a case of a six-year-old girl with ASD and Coffin-Siris syndrome in 1982. Seventh-degree consanguinity was present between her parents. Chromosomal analysis was performed at genetic analysis, but the de novo mutations were not assessed. In the present case, heterozygous c.4176del(p.Tyr 1392*) mutation in the ARID1B gene (6q25.3, NM_020732.3) was determined by whole-exome sequencing. There was no consanguinity between the parents. Both cases met the criteria for ASD in DSM-5 $(8,12)$. Coffin-Siris syndrome is a genetic syndrome caused by mutations at ARID1A, ARID1B, SMARCA4, SMARCB1, SMARCE1 and SOX11 heterozygous pathogenic variants (4). ARID1B gene mutation is the most common cause of the syndrome (5). ARID1B is by far the most frequently mutated gene $(76 \%)$ in Coffin-Siris syndrome (13). ARID1B mutations are rare in autism, although the incidence has not so far been reported (14). ARID1B is also one of the common mutations in autism spectrum disorders (5). The ARID-1 gene is responsible for regulating histone relaxation through the SWI/SNF protein complex. Mutations occurring in the ARID1B gene affect the SWI/SNF protein complex, thus resulting in Coffin-Siris syndrome (15). A group of proteins known as the SWI/SNF chromatin-remodeling complex is responsible for DNA packaging. DNA forms chromatin by coiling up with proteins known as histones. The SWI/SNF protein complex is involved in "neural stem cell/precursor generation, proliferation, and neuronal subtype specification, differentiation, and migration" in the neurodevelopmental process. Dysfunction of the SWI/SNF protein complex affects the neurodevelopmental process and plays a role in the development of neurodevelopmental disorders $(16,17)$. Genes involved in the etiology of autism are associated with neuronal communication, synapse development, and chromatin remodeling/transcription regulation (18-20). Sanders et al. (21) reported that 65 genes encoding either chromatin regulators or synaptic proteins were related to the risk of ASD. The authors suggested that mutations in ARID1 may be associated with ASD due to its presence in the chromatin remodeling/transcription regulation pathway, but that further studies on the subject were needed (16).

ASD is a common neurodevelopmental disorder (22). Identifying the genetic syndromes associated with ASD will contribute to a better understanding of the mechanisms involved in the etiology of ASD. For example, the discovery of $\mathrm{MeCP} 2$ gene mutation in Rett syndrome has revealed its critical role in astrocyte production during neurodevelopment $(23,24)$. Many genetic syndromes comorbid with ASD are also seen in systemic diseases. The early diagnosis of these systemic 
diseases is important in terms of the clinical care needs of patients diagnosed with ASD, too. Thus, an early tumor follow-up program in cases diagnosed with ASD with PTEN mutation, as well as early diagnosis of systemic diseases in tuberous sclerosis patients, and early diagnosis of congenital abnormalities, cardiac, genitourinary, gastrointestinal and craniofacial abnormalities, ophthalmological problems, and hearing abnormalities in patients with Coffin-Siris syndrome may affect the course of the disease $(8,25,26)$. Genetic consultation should be requested for patients diagnosed with ASD in order to identify these diseases. Clinicians should therefore be aware of genetic syndromes in patients diagnosed with ASD (27). Requesting genetic consultation for patients diagnosed with ASD will improve our understanding of the etiology of ASD and is important in terms of early diagnosis of and intervention in systemic diseases (28).

\begin{tabular}{|l|l|l|}
\hline \multicolumn{4}{|l|}{ Contribution Categories } & Author Initials \\
\hline \multirow{4}{*}{ Category 1} & Concept/Design & N.S.G., A.K. \\
\cline { 2 - 3 } & Literature review & N.S.G. \\
\cline { 2 - 3 } & Data analysis/Interpretation & N.S.G., A.K. \\
\cline { 2 - 3 } & Case follow-up (if applicable) & N.S.G. \\
\hline \multirow{3}{*}{ Category 2} & Drafting manuscript & N.S.G., A.K. \\
\cline { 2 - 3 } & Critical revision of manuscript & N.S.G., A.K. \\
\hline Category 3 & Final approval and accountability & N.S.G., A.K. \\
\hline \multirow{2}{*}{ Other } & Technical or material support & N.S.G., A.K. \\
\cline { 2 - 3 } & Supervision & A.K. \\
\hline
\end{tabular}

Acknowledgements: The authors would like to thank the patient and his family for their consent and collaboration.

Informed Consent: Written informed consent was obtained from the patient and his family for the publication of the case report.

Peer-review: Externally peer-reviewed.

Conflict of Interest: The authors declare that they have no conflict of interest.

Financial Disclosure: The authors declared no financial support.

\section{REFERENCES}

1. Hegarty JP, Gengoux GW, Berquist KL, Millan ME, Tamura SM, Karve S, Rosenthal MD, Philips JM, Hardan AY. A pilot investigation of neuroimaging predictors for the benefits from pivotal response treatment for children with autism. J Psychiatr Res 2019; 111:140-144. [CrossRef]

2. Wisniowiecka-Kowalnik B, Nowakowska BA. Genetics and epigenetics of autism spectrum disorder - current evidence in the field. J Appl Genet 2019; 60:37-47.

3. Karayagmurlu A, Gokcen C, Varan C. Morning glory syndrome and autism: a case report. Dusunen Adam The Journal of Psychiatry and Neurological Sciences 2015; 28:167-170. [CrossRef]
4. Tural Hesapcioglu S. Oculocutaneous albinism and autism: a case report and review of literature. Dusunen Adam The Journal of Psychiatry and Neurological Sciences 2013; 26:215-218. [CrossRef]

5. Basgul SS, Saltik S. A case report of Becker's musculer dystrophy presenting with autistic symptoms. Dusunen Adam The Journal of Psychiatry and Neurological Sciences 2012; 25:74-77. (Turkish) [CrossRef]

6. Schrier Vergano S, Santen G, Wieczorek D, Wollnik B, Matsumoto N, Deardorff MA. Coffin-Siris Syndrome: In Adam MP, Ardinger HH, Pagon RA, Wallace SE, Bean LJH, Stephens K, Amemiya A (editors). GeneReviews ${ }^{\circledR}$ [Internet], 2013. [updated 2018 Feb 8].

7. Celen C, Chuang JC, Luo X, Nijem N, Walker AK, Chen F, Zhang S, Chung AS, Nguyen LH, Nassour I, Budhipramono A, Sun X, Bok LA, McEntagart M, Gevers EF, Birnbaum SG, Eisch AJ, Powell CM, Ge WP, Santen GW, Chahrour M, Zhu H. Arid1b haploinsufficient mice reveal neuropsychiatric phenotypes and reversible causes of growth impairment. Elife 2017; 6:e25730.

8. Hersh JH, Bloom AS, Weisskopf B. Childhood Autism in a female with Coffin Siris Syndrome. J Dev Behav Pediatr 1982; 3:249-252.

9. Richards C, Jones C, Groves L, Moss J, Oliver C. Prevalence of autism spectrum disorder phenomenology in genetic disorders: a systematic review and meta-analysis. Lancet Psychiatry 2015; 2:909-916. [CrossRef]

10. Griesi-Oliveira K, Sertie AL. Autism spectrum disorders: an updated guide for genetic counseling. Einstein (Sao Paulo) 2017; 15:233-238. [CrossRef]

11. Alnak A, Bulanik-Ozdemirci D, Coskun M. Co-existence of Beck with Wiedemann Syndrome and Autism Spectrum Disorder. Dusunen Adam The Journal of Psychiatry and Neurological Sciences 2019; 32:268-270.

12. American Psychiatric Association. Diagnostic and Statistical Manual of Mental Disorders Fifth ed. (DSM-5), Washington DC: American Psychiatric Publ., 2013. [CrossRef]

13. Wieczorek D, Bogershausen N, Beleggia F, Steiner-Haldenstatt S, Pohl E, Li Y, Milz E, Martin M, Thiele H, Altmuller J, Alanay Y, Kayserili H, Klein-Hitpass L, Böhringer S, Wollstein A, Albrecht B, Boduroglu K, Caliebe A, Chrzanowska K, Cogulu O, Cristofoli F, Czeschik JC, Devriendt K, Dotti MT, Elcioglu N, Gener B, Goecke TO, Krajewska-Walasek M, Guillen-Navarro E, Hayek J, Houge G, Kilic E, Simsek-Kiper PO, Lopez-Gonzalez V, Kuechler A, Lyonnet S, Mari F, Marozza A, Mathieu Dramard M, Mikat B, Morin G, Morice-Picard F, Ozkinay F, Rauch A, Renieri A, Tinschert S, Utine GE, Vilain C, Vivarelli R, Zweier C, Nurnberg P, Rahmann S, Vermeesch J, Ludecke HJ, Zeschnigk M, Wollnik B. A comprehensive molecular study on Coffin-Siris and Nicolaides-Baraitser syndromes identifies a broad molecular and clinical spectrum converging on altered chromatin remodeling. Hum Mol Genet 2013; 22:5121-5135. [CrossRef]

14. Lai MC, Lombardo MV, Baron-Cohen S. Autism. Lancet 2014; 383:896-910. [CrossRef]

15. Bramswig NC, Caluseriu O, Ludecke HJ, Bolduc FV, Noel NC, Wieland T, Surowy HM, Christen HJ, Engels H, Strom TM, Wieczorek D. Heterozygosity for ARID2 loss-of-function mutations in individuals with a Coffin-Siris syndrome-like phenotype. Hum Genet 2017; 136:297-305. [CrossRef] 
16. Ronan JL, Wu W, Crabtree GR. From neural development to cognition: unexpected roles for chromatin. Nat Rev Genet 2013; 14:347-359. [CrossRef]

17. Sokpor G, Xie Y, Rosenbusch J, Tuoc T. Chromatin Remodeling BAF (SWI/SNF) Complexes in Neural Development and Disorders. Front Mol Neurosci 2017; 10:243. [CrossRef]

18. Pinto D, Pagnamenta AT, Klei L, Anney R, Merico D, Regan R, Conroy J, Magalhaes TR, Correia C, Abrahams BS, Almeida J, Bacchelli E, Bader GD, Bailey AJ, Baird G, Battaglia A, Berney T, Bolshakova N, Bolte S, Bolton PF, Bourgeron T, Brennan S, Brian J, Bryson SE, Carson AR, Casallo G, Casey J, Chung BH, Cochrane L, Corsello C, Crawford EL, Crossett A, Cytrynbaum C, Dawson G, de Jonge M, Delorme R, Drmic I, Duketis E, Duque F, Estes A, Farrar P, Fernandez BA, Folstein SE, Fombonne E, Freitag CM, Gilbert J, Gillberg C, Glessner JT, Goldberg J, Green A, Green J, Guter SJ, Hakonarson H, Heron EA, Hill M, Holt R, Howe JL, Hughes G, Hus V, Igliozzi R, Kim C, Klauck SM, Kolevzon A, Korvatska O, Kustanovich V, Lajonchere CM, Lamb JA, Laskawiec M, Leboyer M, Le Couteur A, Leventhal BL, Lionel AC, Liu XQ, Lord C, Lotspeich L, Lund SC, Maestrini E, Mahoney W, Mantoulan C, Marshall CR, McConachie H, McDougle CJ, McGrath J, McMahon WM, Merikangas A, Migita O, Minshew NJ, Mirza GK, Munson J, Nelson SF, Noakes C, Noor A, Nygren G, Oliveira G, Papanikolaou K, Parr JR, Parrini B, Paton T, Pickles A, Pilorge M, Piven J, Ponting CP, Posey DJ, Poustka A, Poustka F, Prasad A, Ragoussis J, Renshaw K, Rickaby J, Roberts W, Roeder K, Roge B, Rutter ML, Bierut LJ, Rice JP, Salt J, Sansom K, Sato D, Segurado R, Sequeira AF, Senman L, Shah N, Sheffield VC, Soorya L, Sousa I, Stein O, Sykes N, Stoppioni V, Strawbridge C, Tancredi R, Tansey K, Thiruvahindrapduram B, Thompson AP, Thomson S, Tryfon A, Tsiantis J, Van Engeland H, Vincent JB, Volkmar F, Wallace S, Wang K, Wang Z, Wassink $\mathrm{TH}$, Webber C, Weksberg R, Wing K, Wittemeyer K, Wood S, Wu J, Yaspan BL, Zurawiecki D, Zwaigenbaum L, Buxbaum JD, Cantor RM, Cook EH, Coon H, Cuccaro ML, Devlin B, Ennis S, Gallagher L, Geschwind DH, Gill M, Haines JL, Hallmayer J, Miller J, Monaco AP, Nurnberger JI Jr, Paterson AD, Pericak-Vance MA, Schellenberg GD, Szatmari P, Vicente AM, Vieland VJ, Wijsman EM, Scherer SW, Sutcliffe JS, Betancur C.. Functional impact of global rare copy number variation in autism spectrum disorders. Nature 2010; 466:368-372. [CrossRef]

19. Pinto D, Delaby E, Merico D, Barbosa M, Merikangas A, Klei L, Thiruvahindrapuram B, Xu X, Ziman R, Wang Z, Vorstman JA, Thompson A, Regan R, Pilorge M, Pellecchia G, Pagnamenta AT, Oliveira B, Marshall CR, Magalhaes TR, Lowe JK, Howe JL, Griswold AJ, Gilbert J, Duketis E, Dombroski BA, De Jonge MV, Cuccaro M, Crawford EL, Correia CT, Conroy J, Conceicao IC, Chiocchetti AG, Casey JP, Cai G, Cabrol C, Bolshakova N, Bacchelli E, Anney R, Gallinger S, Cotterchio M, Casey G, Zwaigenbaum L, Wittemeyer $\mathrm{K}$, Wing $\mathrm{K}$, Wallace S, van Engeland H, Tryfon A, Thomson S, Soorya L, Roge B, Roberts W, Poustka F, Mouga S, Minshew N, McInnes LA, McGrew SG, Lord C, Leboyer M, Le Couteur AS, Kolevzon A, Jimenez Gonzalez P, Jacob S, Holt R, Guter S, Green J, Green A, Gillberg C, Fernandez BA, Duque F, Delorme R, Dawson G, Chaste P, Cafe C, Brennan S, Bourgeron T, Bolton PF, Bolte S, Bernier R, Baird G, Bailey AJ, Anagnostou E, Almeida J, Wijsman EM, Vieland VJ, Vicente AM, Schellenberg GD, Pericak-Vance M, Paterson AD, Parr JR, Oliveira G, Nurnberger JI, Monaco AP, Maestrini E, Klauck
SM, Hakonarson H, Haines JL, Geschwind DH, Freitag CM, Folstein SE, Ennis S, Coon H, Battaglia A, Szatmari P, Sutcliffe JS, Hallmayer J, Gill M, Cook EH, Buxbaum JD, Devlin B, Gallagher L, Betancur C, Scherer SW. Convergence of genes and cellular pathways dysregulated in autism spectrum disorders. Am J Hum Genet 2014; 94:677-694. [CrossRef]

20. Glessner JT, Wang K, Cai G, Korvatska O, Kim CE, Wood $\mathrm{S}$, Zhang $\mathrm{H}$, Estes $\mathrm{A}$, Brune CW, Bradfield JP, Imielinski $\mathrm{M}$, Frackelton EC, Reichert J, Crawford EL, Munson J, Sleiman PM, Chiavacci R, Annaiah K, Thomas K, Hou C, Glaberson W, Flory J, Otieno F, Garris M, Soorya L, Klei L, Piven J, Meyer KJ, Anagnostou E, Sakurai T, Game RM, Rudd DS, Zurawiecki D, McDougle CJ, Davis LK, Miller J, Posey DJ, Michaels S, Kolevzon A, Silverman JM, Bernier R, Levy SE, Schultz RT, Dawson G, Owley T, McMahon WM, Wassink TH, Sweeney JA, Nurnberger JI, Coon H, Sutcliffe JS, Minshew NJ, Grant SF, Bucan M, Cook EH, Buxbaum JD, Devlin B, Schellenberg GD, Hakonarson H. Autism genome-wide copy number variation reveals ubiquitin and neuronal genes. Nature 2009; 459:569-573. [CrossRef]

21. Sanders SJ, He X, Willsey AJ, Ercan-Sencicek AG, Samocha KE, Cicek AE, Murtha MT, Bal VH, Bishop SL, Dong S, Goldberg AP, Jinlu C, Keaney JF 3rd, Klei L, Mandell JD, Moreno-De-Luca D, Poultney CS, Robinson EB, Smith L, Solli-Nowlan T, Su MY, Teran NA, Walker MF, Werling DM, Beaudet AL, Cantor RM, Fombonne E, Geschwind DH, Grice DE, Lord C, Lowe JK, Mane SM, Martin DM, Morrow EM, Talkowski ME, Sutcliffe JS, Walsh CA, Yu TW; Autism Sequencing Consortium, Ledbetter DH, Martin CL, Cook EH, Buxbaum JD, Daly MJ, Devlin B, Roeder K, State MW. Insights into autism spectrum disorder genomic architecture and biology from 71 risk loci. Neuron 2015; 87:1215-1233. [CrossRef]

22. Bonnet-Brilhault F. Autism: an early neurodevelopmental disorder. Arch Pediatr 2017; 24:384-390. (French) [CrossRef]

23. Liyanage VR, Rastegar M. Rett Syndrome and MeCP2. Neuromolecular Med 2014; 16:231-264. [CrossRef]

24. Amir RE, Van den Veyver IB, Wan M, Tran CQ, Francke U, Zoghbi HY. Rett syndrome is caused by mutations in X-linked MECP2, encoding methyl-CpG-binding protein 2. Nat Genet 1999; 23:185-188. [CrossRef]

25. Conti S, Condo M, Posar A, Mari F, Resta N, Renieri A, Neri I, Patrizi A, Parmeggiani A. Phosphatase and tensin homolog (PTEN) gene mutations and autism: literature review and a case report of a patient with Cowden syndrome, autistic disorder, and epilepsy. J Child Neurol 2012; 27:392-397. [CrossRef]

26. Al-Futaisi A, Idris A, Al-Sayegh A, Al-Mamari WS. Coexistence of autism spectrum disorders among three children with tuberous sclerosis complex: case reports and review of literature. Sultan Qaboos Univ Med J 2016; 16:520-524. [CrossRef]

27. Koparir E, Tarakcioglu MC. Genetic approach and genomic applications in autism spectrum disorder. Turkiye Klinikleri Medical Genetics Topics 2016; 1:69-74. (Turkish)

28. Volkmar F, Siegel M, Woodbury-Smith M, King B, McCracken J, State M; American Academy of Child and Adolescent Psychiatry (AACAP) Committee on Quality Issues (CQI). Practice parameter for the assessment and treatment of children and adolescents with autism spectrum disorder. J Am Acad Child Adolesc Psychiatry 2014; 53:237-257. [CrossRef] 